\title{
Black women in nursing history: the cultural competence in Maria Barbosa Fernandes' trajectory
}

\author{
Mulheres negras na história da enfermagem: a competência cultural na trajetória de Maria Barbosa Fernandes
}

Mujeres negras en la historia de la enfermería: Ia competencia cultural en la trayectoria de Maria Barbosa Fernandes

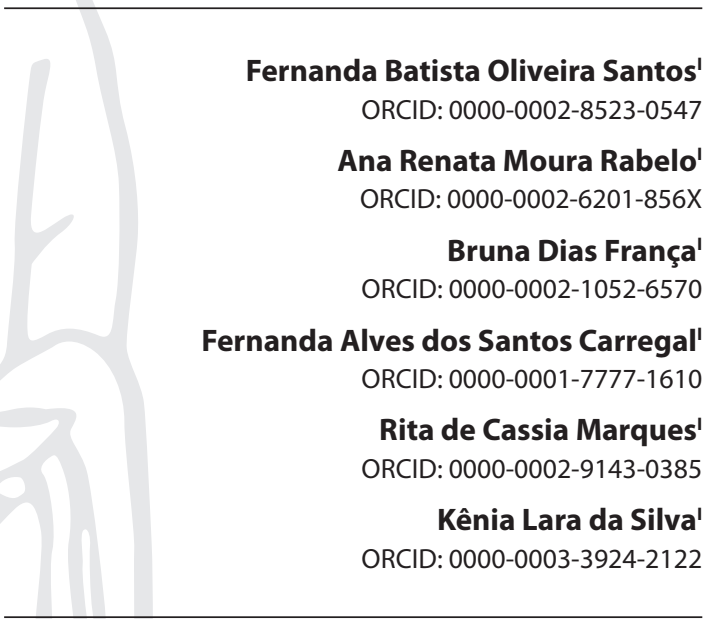

'Universidade Federal de Minas Gerais. Belo Horizonte, Minas Gerais, Brazil.

How to cite this article: Santos FBO, Rabelo ARM, França BD, Carregal FAS, Marques RC, Silva KL. Black women in nursing history: the cultural competence in Maria Barbosa Fernandes' trajectory. Rev Bras Enferm. 2020;73(Suppl 4):e20190221. doi: http://dx.doi.org/10.1590/0034-7167-2019-0221

\section{Corresponding author:}

Fernanda Batista Oliveira Santos

E-mail: fernandabosufmg@gmail.com

EDITOR IN CHIEF: Dulce Aparecida Barbosa ASSOCIATE EDITOR: Ana Fátima Carvalho Fernandes

Submission: 08-16-2019

Approval: 01-10-2020

\section{ABSTRACT}

Objectives: to know the professional trajectory of the black nurse Maria Barbosa Fernandes and to analyze elements of her professional practice based on the cultural competence model of CampinhaBacote. Methods: historical-social study with an analysis of the findings in light of the Cultural Competence model. Results: Maria Barbosa was the first black woman to earn a nursing degree at the Escola de Enfermagem Carlos Chagas (Carlos Chagas Nursing School) (1935-1938), and the documentation about her history allowed us to infer the experience of discrimination and invisibility. However, her professional trajectory was marked by careful attention to the singularities and the sociocultural reality of individuals, with an emphasis on acting in vulnerable scenarios. Final Considerations: the pairing of the theme of black women in nursing with the reference of Cultural Competence consists of an invitation to value diversity in the profession and seek to move towards care committed to overcoming inequalities, through inclusive practices and culturally sensitive care.

Descriptors: History of Nursing; Education, Nursing; Cultural Competency; Women; Socioeconomic Factors.

\section{RESUMO}

Objetivos: conhecer a trajetória profissional da enfermeira negra Maria Barbosa Fernandes e analisar elementos de sua prática profissional a partir do modelo de competência cultural de Campinha-Bacote. Métodos: estudo histórico-social com análise dos achados à luz do Modelo de Competência Cultural. Resultados: Maria Barbosa foi a primeira mulher negra a diplomar-se enfermeira na Escola de Enfermagem Carlos Chagas (1935-1938), e a documentação sobre a sua história permitiu inferir a vivência de discriminação e invisibilidade. Entretanto, sua trajetória profissional foi marcada por cuidados atentos às singularidades e à realidade sociocultural dos indivíduos, com destaque para a atuação em cenários de vulnerabilidade. Considerações Finais: o pareamento da temática da mulher negra na enfermagem ao referencial de Competência Cultural consiste em um convite à valorização da diversidade na profissão e à busca de avançar em direção ao cuidado comprometido com a superação de desigualdades, por meio de práticas inclusivas e cuidados culturalmente sensíveis.

Descritores: História da Enfermagem; Educação em Enfermagem; Competência Cultural; Mulheres; Fatores Socioeconômicos.

\section{RESUMEN}

Objetivos: conocer la trayectoria profesional de la enfermera negra Maria Barbosa Fernandes y analizar elementos de su práctica profesional a partir del modelo de competencia cultural de Campinha-Bacote. Métodos: estudio histórico-social con análisis de los hallazgos a la luz del Modelo de Competencia Cultural. Resultados: Maria Barbosa ha sido la primera mujer negra a diplomarse enfermera en la Escuela de Enfermaría Carlos Chagas (1935-1938) y la documentación sobre su historia permitió inferir la vivencia de discriminación e invisibilidad. Entretanto, su trayectoria profesional ha sido marcada por cuidados atentos a las singularidades y a la realidad sociocultural de los individuos, con destaque para la actuación en escenarios de vulnerabilidad. Consideraciones Finales: el emparejamiento de la temática de la mujer negra en la Enfermaría al referencial de Competencia Cultural consiste en una invitación a la valorización de la diversidad en la profesión y a la búsqueda de avanzar en dirección al cuidado comprometido con la superación de desigualdades, por medio de prácticas inclusivas y cuidados culturalmente sensibles.

Descriptores: Historia de la Enfermaría; Educación en Enfermaría; Competencia Cultural; Mujeres; Factores Socioeconómicos. 


\section{INTRODUCTION}

Social inequalities, in different sectors and aspects, permeate the history of Brazilian society. In the health sector, in particular, to recognize the different needs of social groups through universal and redistributive policies is to assume the notion of equity advocated by the Brazilian Health Reform ${ }^{(1)}$.

As a way to face inequalities, there are several strategies, emphasizing the performance of nursing. In a perspective of care as a social practice, the work of nursing consists of reducing risks, guiding, educating, training, informing, promoting social participation in the elaboration of public policies and participating in self-care processes, considering individuals who are open, ecological, in balance, with the capacity to take care of themselves: self-eco-organizers ${ }^{(2-3)}$.

Thus, when we take into account that the performance of nursing is marked by several inequalities that permeate the social reality of the assisted patients, the theoretical framework of Cultural Competence stands out. Furthermore, it is considered that diversity among the leaders of nursing is essential to develop inclusive practices and provide culturally sensitive care ${ }^{(4)}$.

Thus, Cultural Competence has been studied as an approach to reduce health inequalities through effective and culturally responsive services, regarding the ethnic and cultural diversity of the individuals $s^{(5)}$. Initially, the studies provided by the reference of Cultural Competence focused on racial and ethnic differences. However, they also started to include other marginalized population groups at risk of stigmatization, in addition to race and ethnicity, or who have differences in health care needs that result in inequities ${ }^{(6)}$.

Moita and Silva (2016), from the critical study, carried out on existing theoretical and methodological models of Cultural Competence, emphasize the procedural aspect of the development of this competence in a continuous, dynamic, and continuously evolving manner ${ }^{(6)}$.

Among the references of Cultural Competence, there is the model proposed by CampinhaBacote, which is developed within the scope of health care providers and includes the fields of Transcultural Nursing, Medical Anthropology, and Multicultural Counseling. In this model, Cultural Competence is understood as a process, based on five integrated dimensions, namely: cultural awareness, cultural knowledge, cultural skill, cultural encounters, and cultural desire. Such elements are related, and there is no static definition for each ${ }^{(5)}$.

Through a re-reading of such a model, it is possible to understand that cultural awareness results from the way individuals examine their professional and personal experience, identifying prejudices and assumptions. Cultural knowledge relates to learning about the cultural diversity of groups. Cultural skill consists of developing skills to collect cultural information and act in a culturally relevant approach. The term cultural encounters relate to the interaction between culturally diverse groups, and cultural desire would be like a self-motivation to become culturally competent $t^{(7)}$. The reading by Gonzáles (2013) of the CampinhaBacote model helps in the integration of the various dimensions from the emphasis given to cultural desire, to the genuine way of motivating the person or professional ${ }^{(8)}$. Motivation, in turn, mobilizes the other dimensions, the use, and development of cultural skills and knowledge, and, still, the movement towards the direction of (self) encounters.

In this context outlined by nursing, inequalities and Cultural Competence, the insertion of the egress Maria Barbosa Fernandes (from 1935 to 1938) at the Escola de Enfermagem Carlos Chagas (EECC - Chagas Carlos Chagas Nursing School) stands out (the EECC gave rise to the Escola de Enfermagem da Universidade Federal de Minas Gerais - EEUFMG - Nursing School of the Federal University of Minas Gerais). Maria Barbosa was a black woman who dedicated herself to take care of marginalized audiences and whose presence marks the beginning of the flexibility of the teaching space for the insertion of women out of the standard for the time at professional nursing from Minas Gerais. The profile of this former student at EECC drew the researchers' attention for being the first black woman to graduate from the school and for her professional trajectory to be marked by nursing care sensitive to the uniqueness and sociocultural reality of human beings.

Studying and understanding nursing based on gender stereotypes is still an incipient movement in Brazilian research; and, from this fact, undertaking this study constituted an important challenge to be transgressed. We believed that the understanding of Maria Barbosa's historical trajectory would allow us to reflect on the importance of the development of Cultural Competence for the nurses' training and practice.

\section{OBJECTIVES}

To know the professional trajectory of the black nurse Maria Barbosa Fernandes and to analyze elements of her professional practice based on the cultural competence model of CampinhaBacote ${ }^{(5)}$.

\section{METHODS}

\section{Ethical aspects}

The study focused on documentary sources available for public consultation, being exempt from the opinion of a Research Ethics Committee.

\section{Type of study}

Research of a historical-social nature, which included a qualitative analysis of the findings. It is part of the studies that have been developed by the Núcleo de Estudos e Pesquisas sobre Ensino e Prática de Enfermagem (NUPEPE- Center for Studies and Research on Nursing Teaching and Practice). The NUPEPE includes research lines concerning studies about nursing formation and practice. It also has been making efforts in studies regarding social inequalities and competencies for nurses'training, including the historical dimension of the profession.

\section{Methodological procedures}

The approximation with the references of Cultural Competence made the researchers, who also work with historical studies, look over the collection of the Centro de Memória da 
Escola de Enfermagem da Universidade Federal de Minas Gerais (CEMENF-UFMG - Memory Center of the Nursing School of the Federal University of Minas Gerais). This look made us realize that Maria Barbosa's profile was an excellent example of how nurses, impacted by social issues, can add skills to reduce inequalities.

\section{Study scenario}

The study scenario was the city of Belo Horizonte, capital of the state of Minas Gerais, in the 1930s, 1940s, and 1950s. It is in this context that the main events analyzed in the professional trajectory of Maria Barbosa Fernandes took place: the Carlos Chagas Nursing School, the institutions where she worked as a nurse, and her outstanding work with prostitutes in the central region of the city.

\section{Data source}

We collected the data from three main documents that are under the custody of the CEMENF-UFMG: Maria Barbosa Fernandes registration form at Carlos Chagas Nursing School (1935) (9); interview granted by the graduate in $1998^{(10)}$; Jornal Cinco pras Dez (Five to ten New), produced by women internal students of the EECC in the 1930 s and $1940 s^{(11)}$.

\section{Data collection and organization}

With the documents in hand, we sought to highlight Maria Barbosa's most significant contributions to the qualification of culturally competent nursing care. The CEMENF collection was consulted in the second half of 2018.

\section{Data analysis}

After a survey of documentary sources that made it possible to investigate the past of the first black woman trained at the EEUFMG / EECC, we analyzed the findings in the light of the Cultural Competence model ${ }^{(5)}$.

\section{RESULTS}

The Federal University of Minas Gerais School of Nursing originated from EECC. The Carlos Chagas School was created on July 7, 1933, in the state of Minas Gerais and sought to follow the parameters of the model school of modern nursing in the country, the Escola de Enfermagem Anna Nery (EEAN - Anna Nery Nursing School), conquering the Anna Nery standard in $1942^{(12-13)}$.

Following the Anna Nery standard, EECC modeled its scope of incoming students for the non-acceptance of neither black men nor women, profiles that were present in the Brazilian nursing before the arrival of the Mission Parsons. Thus, the selection criteria considered a nightingale archetype of the model nurse: white, young, middle-class, and formally educated women ${ }^{(14)}$.

However, the expectations for adhesion of this social layer in the EECC have not been fulfilled since its creation. The need to train nurses to meet the demands of Brazilian public health forced nursing schools to accept women outside the standard for the time, thus expanding the possibility for black women to enter nursing schools, including the EECC.

This setting was the context of Barbosa Fernandes. She was born on September 15, 1918, in Santa Bárbara, a municipality in the interior of the state of Minas Gerais. She had no memories of her homeland, as her father's aunts raised her in Belo Horizonte, where she attended elementary school (Grupo Escolar Barão de Macaúbas, Floresta district), the gymnasium and the professional development in accounting. Her parents stayed in Santa Bárbara (her father worked on the railway; they were five children: two married men, two single women, and Maria Barbosa; after a few years, they all went to live in the capital of Minas Gerais). Single, she reported having raised an adopted son. She was catholic(9-11).

She learned about the Nursing Course at EECC through an instructor at the School - Edelvira Costa Santos. The interest came from the curiosity she felt when seeing the uniform that Edelvira was wearing: "This nun is different." Maria Barbosa tells that, at the beginning of the course, she was afraid of the corpses and disgusted by them because of her fear of dying, but then she got used to it. The classes were joint with the students of the Faculty of Medicine. She reported that nursing students were very concerned because the director Laís Moura Netto dos Reys used to say: "Don't try anything funny." Medical students were funny and called them "repentant Magdalenes" because of their veil(10).

Encouraged by her aunt, she took the selection tests (general knowledge test) and joined EECC in 1935. At that time, it was necessary to pay for the school, a small amount, but Maria, in her interview, did not say who paid the expense ${ }^{(10)}$. She graduated in 1938, still under the management of Laís Moura Netto dos Reys. While a student at EECC, Maria Barbosa worked at Hospital São Vicente, currently Hospital das Clínicas, UFMG. The theoretical classes were given at the Faculty of Medicine, and she did an internship at Hospital São Vicente, at Santa Casa of Belo Horizonte (Public hospital), at Emergency care hospital and the Tuberculosis Dispensary in Morro das Pedras ${ }^{(10)}$.

After graduating, she did a public health internship in Salvador (Bahia) with the support of Marina Andrade Resende (graduated from EECC and an essential figure in the Associação Brasileira de Enfermagem - ABEn-Brazilian Nursing Association). She worked at the Emergency care hospital in Belo Horizonte, now João XXIII Hospital, for 8 years, guiding students of the school, including Waleska Paixão, later director of EECC, in the period of 1940-1948(10).

Later, she worked in public health, making home visits to the brothels on Guaicurus Street and Santos Dumont Avenue (in the bohemian zone of Belo Horizonte) and guiding patients with venereal diseases at the Carlos Chagas Health Center. She reported that it was a "rewarding experience":

Look, in public health, I started working in the red light (laughs). People said at the time: Oh !, I said it didn't matter, everything is work. (...) I had to go to all the houses, talk to the women, the hotels. Because at the time, many sick people were showing up at the casino. (...) I have nothing to complain; they (the prostitutes) treated me very well. Sometimes they spoke to me: 'You can't stay here' (not to be confused with a prostitute). Then I answered like this: I can, I'm a nurse, I need to talk to her (the prostitute) and everyone already knows me because we went with the veil and everything. (...) When I arrived at the hotels, I looked for the manager, and the manager called: Hey, the nurse is here. If you 
are busy, do not open the door, whoever is free, please come here. (...) They told me about their lives. It was misery! In Lagoinha (Belo Horizonte district-MG), there was a place called "Buraco Quente" (Hot Hole). It was terrible there, you know? The sewage was blown up, all that dirt falling, we didn't even know where to step. I even arranged for a wedding for them to change their lives and all. But there were some that it didn't matter and they ended up dying, you know? Raped, murdered, and everything ${ }^{(10)}$.

She also worked with students in internships at the Hugo Werneck Nursing School, currently the Nursing School of the Pontifícia Universidade Católica (PUC-MG - Pontifical Catholic University). She also had very active participation in the Associação Brasileira de Enfermagem - Seção Minas Gerais (ABEn-MG - Brazilian Nursing Association - Minas Gerais Section) and retired in 198, after 50 years as a professional ${ }^{(10)}$.

Maria Barbosa reported that there were other black women at EECC, but that they gave up, and she was the first black woman to graduate. Despite stating in her interview that she did not suffer prejudice, the EECC newspaper, called Cinco pras Dez (Five to ten) (11), mentions Maria Barbosa as an invisible human being, making fun of the fact that she is shy and little talkative:

\section{DISCUSSION}

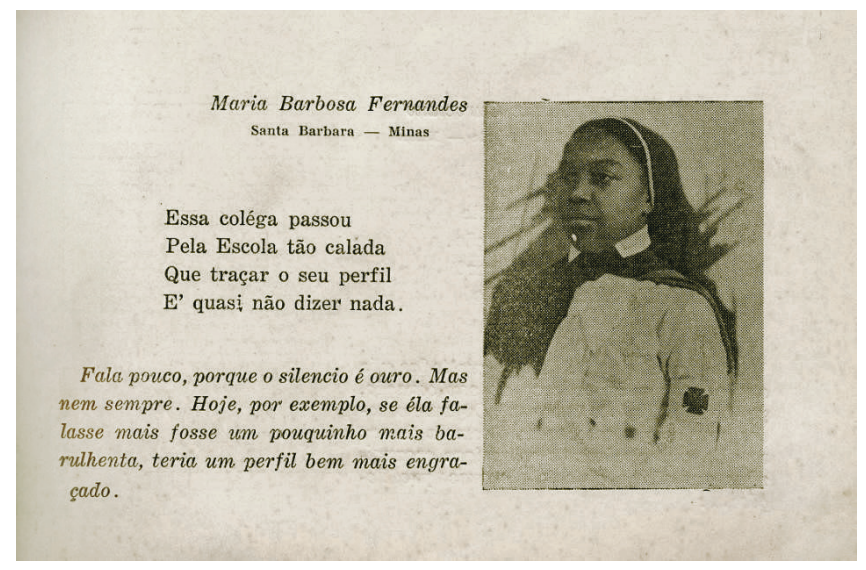

Source: Jornal Cinco pras Dez (Five to Ten newspaper), Collection of CEMENF-UFMG. Figure 1 - Memorial, Maria Barbosa Fernandes

\section{Maria Barbosa Fernandes: black woman and nurse}

In the nursing context in the first half of the 20th century, the envision was the practice professionalization by the emergence of the first formal schools. At that time, there was an ideal profile of students in order to raise the status of care, previously characterized by disqualifying representations. Thus, the inclusion criteria in the courses included: being a white woman, having a vocation for the art of care, having an educational and religious background, preferably Christian ${ }^{(14)}$.

These definitions increased the distances between black and white people in nursing and, the process of legitimizing the profession through the high valuation of the Nightingale model, disregarded the practices historically performed by black caregivers, roots of care in Brazil among the elderly, sick and children were ${ }^{(15)}$.
Pires, Fonseca, and Padilla (2016) made a reflection on gender stereotypes in the nursing profession based on the analysis of inequalities experienced by Brazilian women in Portugal and, in turn, by Brazilian nursing. The Judeo-Christian culture, which dichotomizes the variables fragile or strong, victim or guilty and holy or sinful, sees the Brazilian woman as a mulata, sensual, exotic, and sexual; in contrast to the Portuguese woman, associated with whiteness and images of sanctity and purity ${ }^{(16)}$.

Similar to the insertion of Brazilian women in Portugal, the entry of black women into the nursing profession - under the influence of Christian morality - was considered undesirable. That is because the Nightingale model expected white, sanctified, pure representations associated with benevolence, charity, and nobility of nursing, and black women were hypersexualized, considered sinners, source of danger, of contagion of diseases, ignorant, degenerate and undisciplined ${ }^{(15-16)}$.

In this sense, EECC, as the first nursing school in Brazil located outside the state of Rio de Janeiro ${ }^{(13)}$, opened space for students outside the desired standard at the time. Thus, Maria Barbosa Fernandes joined in 1935, being the first black woman to become a nurse at EECC. The School selection process did not have a document describing the criteria for evaluating the intended profile, which was subject to subjective evaluation by the management.

Although unwanted, blacks, pardas (brown), and mulatas begin to enroll in nursing schools. A study, with a time frame from 1940 to 1960, on the sociocultural characteristics of the students at Escola Luiza de Marilac, the first in Rio de Janeiro for religious women molded according to the official Anna Nery standard, found a high dropout rate among black students. Some transferred to other schools of nursing or alleged health problems to do not continue studying. None were excluded due to disciplinary problems or insufficient academic performance. Also, it is necessary to consider financial difficulties, even if they do not appear in official reports as a reason for withdrawal ${ }^{(17)}$.

The development of public health contextualizes the opening to students who differ from the desired standard for the time, which generated a high demand for professionals - the national context called for reforms in this field, which faced a dramatic health situation.

In order to improve public health in the country, the government of Getúlio Vargas (19301945) invested in political, training strategies, and national services responsible for campaigns to combat endemic diseases. An important strategy used was the investment in the training of health doctors and nurses in order to prevent and combat the diseases that afflicted the population at the time (tuberculosis, malaria, yellow fever, and plague) ${ }^{(12)}$. This context is the scenario experienced by Maria Barbosa. It is worth mentioning that its characteristics and the training needs of nurses imposed by such a situation overlapped prejudice, contributing to her entry into the EECC's Nursing course.

Maria Barbosa was single, Catholic, was born in the interior of Minas Gerais but was raised in the state capital. She attended Nursing at a time when there was a need for a financial contribution to pay for studies at EECC - and, importantly, in a historic moment when the great concern of women was to get a good marriage and be a mother ${ }^{(18)}$. Maria Barbosa challenged the established standards when adopting a child and seeking the profession in nursing, albeit out of "curiosity" and family encouragement. 
Concerning Maria Barbosa's social position as a black woman, Social Science studies point out the effects of globalization and, consequently, of colonization on power relations and gender and race inequalities. The entry of white European men in colonized countries resulted in the positioning of women and native blacks as non-human beings ${ }^{(19)}$. Furthermore, capitalism, as founded on the exploitation of peoples and nature, is associated with an anthropological context in which "women are for men, just as nature is for culture" ${ }^{\prime \prime 20)}$. It is important to note that the women researchers cited in this paragraph do not understand that inequality is an isolated product of colonialism/globalization, but that these movements had effects on the phenomenon of gender and race inequality.

We also considered that the position occupied in society is tangible by the crossing of several markers of oppression on the bodies of women, especially race/color and sexual orientation ${ }^{(21)}$, but also including aspects of income/socioeconomic condition, generation, and regionalization. Therefore, Maria Barbosa's profile, described in the results, may partially explain her silencing reported by colleagues at the memorial: "This colleague passed by the school so quietly."

In another way, we noted the occurrence of an independent practice when considering that Maria Barbosa entered innovative performance spaces, such as the brothels. This fact may be related to the status of legitimacy conferred to her by the title of nurse, despite being a black woman. That is, from the point of view of power relations, being a nurse gives a different position because of the access to legitimate health knowledge.

Furthermore, it is noteworthy that the historical characteristics of health practices in the period reported here were marked by a gradual transition from eugenist and imposing approaches to approaches aimed at changing behavior, encompassing a dialogical and situational approach ${ }^{(22)}$. Thus, Maria Barbosa presented elements of an advanced practice of nursing, characterized by the concern with the subjectivity of the individuals and different performance scenarios.

\section{Nursing practice by Maria Barbosa and Cultural Competence}

Concerning Maria Barbosa's practice, an analysis was carried out based on the Cultural Competence Model(5), considering the following elements: cultural awareness, cultural knowledge, cultural skill, cultural encounters, and cultural desire.

Data from the interview with Maria Barbosa show that she denied experiencing prejudice because she is a black woman in the nursing profession. However, when analyzing the image and news taken from the memorial, it is noted the existence of discriminatory and prejudiced practices directed at her. Similarly, first Afro-Brazilian students at the São Paulo School of Nursing faced episodes of racial discrimination and demotion, despite the prominence in professional life, reaching merits and honors ${ }^{(23)}$.

Experiences of discrimination and depreciation were common throughout the education and practice of black nurses, resulting in feelings of marginalization and isolation ${ }^{(4)}$. Thus, it is possible to infer that there is a discursive interdiction by Maria Barbosa about power relations and experiences of racism, triggered by the fact that she is a black woman, with a profile that is not standard for the time in professional nursing in Minas Gerais.
It is possible to infer that the fact of being a black woman in nursing, and the experience of discriminatory situations influenced Maria Barbosa's self-examination, her self-awareness, her recognition of her place. Under the Cultural Competence model, these are essential factors for analysis concerning cultural awareness in relation to the proper values and influences on the care provided. Perhaps the recognition of oneself, favored by contexts with less impact of blackness for the profession, contributed to the potential for culturally appropriate care.

Concerning cultural knowledge, regardless of an analysis of the course content of Nursing, the account of Maria Barbosa's practice demonstrates that she had an understanding of the value of the human person in cultural diversity and the possibilities of care as a social practice (emphasized by the concern about the patients' point of view, comprehensiveness, sanitary conditions and also aspects of intimate and social life, such as violence and abuse). She may have developed such knowledge in personal and professional experiences, internships, and her enrollment in ABEn-MG.

Continuing the discussion about Cultural Competence model, in relation to cultural skill, her dialogical communication stands out (being open to reports, relating "with the manager" of the hotels), supported by observation skills, knowledge, and legitimacy conferred by the profession (being a nurse) to enter spaces considered inappropriate for a woman at that time.

The historic milestone for discussing counseling on sexually transmitted diseases occurred only in 1980, during the Brazilian (re) democratization process. This counseling should be carried out by health professionals at a higher level, and the counselor's job was to inform, assess risks, and provide emotional support ${ }^{(24)}$. This fact reaffirms Maria Barbosa's position as a woman ahead of her time, as she already used this strategy about 40 years before that period.

It is possible to analyze the cultural encounters in the care scenes that were routinely produced by Maria Barbosa's performance, whether at home visits, the guidance of venereal diseases, monitoring of students, or in the concern with the adaptation to the other's language. Thus, in the course of her practice, it is noted that there was interaction with culturally diverse groups - meeting of health professionals, nursing students (both groups residing in central Belo Horizonte from low risk) and drug users, living in a highly vulnerable neighborhood in Belo Horizonte (Lagoinha, neighborhood in the Northwest region).

The cultural desire arises in reports about Maria Barbosa, regarding her motivation in favor of a differentiated practice and a differentiated public, and her openness to learning from others. More than having to go to the places previously neglected, Maria Barbosa wanted to know the reality of the other, she wanted to change the reality, including trying to "arrange marriage" for prostitutes; she was concerned with local conditions and the sanitation of the areas through which she passed.

\section{Study limitations}

When unveiling the story of Maria Barbosa Fernandes, the uniqueness of this black woman was revealed, which may or may not have been the reality of so many other black women nurses 
in Brazil. Therefore, this study does not propose the generalization of these findings since we assume that the different social, economic, political, and cultural contexts are determining elements to outline other individuals with different characteristics in the same historical times or others.

\section{Contributions to the nursing field}

Exposing part of our profession's history, pointing out lively discussions to delineate the directions that were given to the professionalization of Brazilian nursing in the first half of the twentieth century, such as black women's difficulty insertion and acceptance, was an opportunity to reflect on the profession and on the genesis of so many inequalities that are formed in it and beyond it in our society.

Assuming the relevance of culturally competent care, as did the egress of EECC, Maria Barbosa Fernandes, opened up a range of questions about if we have genuinely involved ourselves in overcoming these inequalities.

We believe that this exercise of rethinking the practice and training of nurses from the perspective of approximation with Cultural Competence can meet a pressing demand from the Brazilian population for sensitive care, (re) meaning in its essence.

\section{FINAL CONSIDERATIONS}

Adopting the themes of race and ethnicity in nursing is a significant challenge because it is a topic that is not always comfortable and challenges conventional thinking. A critical approach was needed that included power relations and discursive effects on individuals and institutions. We invested in a discussion that parallels the theme to the reference of Cultural Competence, looking for ways to move towards the care committed to overcoming inequalities, crucial needs even today.

The analyzed history and practice demonstrate the intersection, in the figure of Maria Barbosa, of elements from the five dimensions of the Cultural Competence process described by CampinhaBacote, developed either by Maria Barbosa's professional training or her own living experience. Also, the analysis carried out on Maria Barbosa's practice, based on the Campinha-Bacote model, shows that Cultural Competence results in fact in the possibility of offering care committed to overcoming inequalities that strongly influence the context of health.

Therefore, by breaking with the nurse stereotypes expected at the time and dedicating herself to nursing in a culturally competent way, Maria Barbosa presents herself as a necessary "character" for the history of nursing and for changing the practice.

It is necessary to consider that institutional and historical discourses perpetuate barriers to black professionals in nursing, resulting in its invisibility. This study deserves to be highlighted as an instrument of visibility of the contributions of black women to nursing and Brazilian public health, in a historic commitment that must be assumed, so as not to allow such discrimination and oppression to continue occurring in the profession and society.

In the current context, it is mandatory to consider that the selection processes for admitting university candidates in Brazil have undergone many changes that provide greater transparency and reduced subjectivity in the entry criteria, in addition to the quota system that supports the reduction of asymmetries in opportunities to enter education. However, insertion is only one step, as inequalities are still vast in the teaching (and work) environment, which constitutes an invitation to understand this study not as something overcome, but as a prioritized agenda to be faced concretely by nursing.

\section{REFERENCES}

1. Miranda GMD, Mendes ACG, Silva ALA. Public policies challenges on the background of demographic transition and social changes in Brazil. Interface. 2017;21(61):309-20. doi: 10.1590/1807-57622016.0136

2. Salviano MEM, Nascimento PDFS, Paula MA, Vieira CS, Frison SS, Maia MA, Souza KV, Borges EL. Epistemology of nursing care: a reflection on its foundations. Rev Bras Enferm. 2016;69(6):1172-7. doi: 10.1590/0034-7167-2016-0331

3. Queirós PJP. Reflections for a nursing epistemology. Texto Contexto Enferm. 2014 [cited 2019 Mar 13]; 23(3):776-81. doi: 10.1590/0104-07072014002930013

4. Jefferies k, Goldberg L, Aston M, Murphy GT. Understanding the invisibility of black nurse leaders using a black feminist poststructuralist framework. J Clin Nurs. 2018 [cited 2019 Mar 13];27(15-16):3225-34. doi: 10.1111/jocn.14505

5. Campinha-Bacote J. The process of Cultural Competence in the Delivery of Healthcare Services: a model of care. J Transcult Nurs. 2002 [cited 2019 Mar 13];13(3):181-4. doi: 10.1177/10459602013003003

6. Moita MAG, Silva AL. Modelos de Competência Cultural: Uma Análise Crítica. Pensar Enferm [Internet]. 2016 [cited 2019 Mar 13];20(2):72-88. Available from: http://pensarenfermagem.esel.pt/files/Doc4_72_88.pdf

7. Kohlbry PW. The Impact of International Service-Learning on Nursing Students' Cultural Competency. J Nurs Scholarsh. 2016[cited 2019 Mar 13];48(3):303-11. doi: 10.1111/jnu.12209

8. Marrero González, CM. Enfoque del modelo de Purnell y Campinha-Bacote en la práctica de los profesionales sanitarios. Rev Enferm. 2013 [cited 2019 nov 26];7(3). Available from: http://ene-enfermeria.org/ojs/index.php/ENE/article/view/278.

9. Fernandes MB. Ficha de Inscrição na Escola de Enfermagem Carlos Chagas. Belo Horizonte (MG): Centro de Memória da Escola de Enfermagem da UFMG; 1935.

10. Fernandes MB. Entrevista. Belo Horizonte (MG): Centro de Memória da Escola de Enfermagem da UFMG; 1998; I(IV):22. 
11. Memorial Maria Barbosa Fernandes. Jornal Cinco praz dez. Escola de Enfermagem Carlos Chagas. Belo Horizonte (MG): Centro de Memória da Escola de Enfermagem da UFMG;1938; I(VI):3.

12. Santos FBO, Marques RDC. Nurses graduated from Escola de Enfermagem Carlos Chagas: Work areas. 1936-1948. Esc Anna Nery. 2015[cited 2019 Mar 13];19(2):363-8. doi: 10.5935/1414-8145.20150050

13. Santos FBO, Carregal FAS, Rodrigues RD, Marques RDC,Sena RRD. História da enfermagem brasileira (1950-2004): o que tem sido discutido na literatura? Rev Enferm Cent-Oeste Min. 2018[cited 2019 Mar 13];8(e):1-14. doi: 10.19175/recom.v7i0.1876

14. Lombardi MR, Campos VP. A enfermagem no Brasil e os contornos de gênero, raça/cor e classe social na formação do campo profissional. Rev ABET [Internet]. 2018[cited 2019 Mar 13];17(1):28-46. doi: 10.22478/ufpb.1676-4439.2018v17n1.41162

15. Campos PFS. O debate entre história e enfermagem pré-profissional nas aquarelas de Jean-Baptiste Debret (1816-1831). Cult Cuid. 2015[cited 2019 Mar 13];19(43):95-105. doi: 10.14198/cuid.2015.43.10

16. Pires MRGM, Fonseca RMGS, Padilla B. Policy of care in the criticism towards gender stereotypes. Rev Bras Enferm. 2016[cited 2019 Mar 13];69(6):1156-62. doi: 10.1590/0034-7167-2016-0441

17. Ferreira LO, Brotto RB. Nordestinas and normalistas: A study on the sociocultural characteristics of the students of a Catholic nursing school in Brazil (1940-1960). Hist Unisinos [Internet]. 2018[cited 2019 Jun 11]; 22(4):579-591. doi: 10.4013/htu.2018.224.06

18. Vasconcelos MCC. Uma mulher educada no oitocentos: a escrita feminina no Diário da Viscondessa de Arcozelo. Revista Educação em Questão.2015[cited 2019 Mar 13];53(39):104-31. doi: 10.21680/1981-1802.2015v53n39ID8522

19. Lugones M. Rumo a um feminismo descolonial. Est Fem [Internet]. 2014 [cited 2019 Aug 11];22(3):935-52. Available from: https://periodicos. ufsc.br/index.php/ref/article/view/36755/28577

20. Ortner Sherry B. Está a mulher para o homem assim como a natureza para a cultura? In: Rosaldo, Michelle Zimbalist; Lamphere, Louise. A Mulher, a cultura e a sociedade [Internet]. Rio de Janeiro: Paz e Terra. 1979 [cited 2019 Nov 26];95-120. Available from: http://repositorio. ufba.br/ri/handle/ri/19074

21. Davis A. Mulheres, raça e classe. São Paulo: Boitempo Editorial; 2016. 248p.

22. Carvalho FFB. A saúde vai à escola: a promoção da saúde em práticas pedagógicas. Physis (Rio J.). 2015[cited 2019 Mar 13];25(4):1207-27. doi: 10.1590/S0103-73312015000400009

23. Campos PFS, Carrijo AR. llustre inominada: Lydia das Dôres Matta e enfermagem brasileira pós-1930. Hist Cienc SaúdeManguinhos [Internet]. 2019[cited 2019 Aug 16];26(1):165-185. doi: 10.1590/s0104-59702019000100010

24. Galindo WCM, Francisco AL, Rios LF. Reflexões sobre o Trabalho de Aconselhamento em HIV/Aids. Trends Psychol. 2015 [cited 2019 Mar 13];23(4):815-29. doi: 10.9788/TP2015.4-02 